\title{
PROBLEMATIKA BIMBINGAN DAN KONSELING BIDANG AKADEMIK PESERTA DIDIK SMA: A SYSTEMATIC LITERATURE REVIEW (SLR)
}

\author{
Ma'rifatin Indah Kholili, Duta Akbar Nugroho, Dwi Nur Khasanah, Imas \\ Ayu Inggil Pangestuti \\ Universitas Sebelas Maret \\ Email: marifatin.ink@staff.uns.ac.id
}

\begin{abstract}
Abstrak
Penelitian ini bertujuan untuk mengetahui problematika akademik serta upaya penangannya pada peserta didik di SMA. Metode yang digunakan yaitu Systematical Literatur Review (SLR) dengan mengumpulkan referensi dari berbagai jurnal dalam rentang waktu dari 2010-2020. Analisis data menggunakan pendekatan kualitatif metode meta sintesis, yaitu metode yang berupaya mengidentifikasi, mengevaluasi, dan menginterpretasi keseluruhan hasil penelitian sesuai dengan pertanyaan penelitian, topik, ataupun fenomena yang menjadi kajian. Hasil temuan penelitian ini yaitu terdapat berbagai macam problematika bidang akademik yang dialami oleh peserta didik SMA, seperti: prokrastinasi akademik, hasil belajar rendah, keterampilan berbicara rendah, cyberloafing, self-efficacy, stres akademik, student truancy, meningkatkan student engagement, tanggungjawab belajar rendah, kemandirian belajar rendah, regulasi diri rendah, capaian akademik rendah, dan motivasi belajar rendah. Sedangkan strategi penanganan yang ditawarkan diantaranya adalah: cognitive behavior modification teknik self-control, teknik self management dengan aplikasi any.do, cooperrative learning, modeling simbolik, konseling kelompok teknik self-control, cinema therapy, progressive muscle relaxation, video tutorial strategi problem focused coping, kelompok behavioral teknik self-manajement dan reinforcement, clasical format mindfulness deep breathing, strategi self-manajement, bimbingan kelompok metode problem solving, contextual teaching and learning dengan pendekatan ahli, konseling behavioral teknik self-manajemen, teknik relaksasi, konseling kelompok teknik problem solving, bimbingan kelompok teknik stimulus, konseling kelompok berbasis solusi, strategi coping, dan quantum learning.
\end{abstract}

Kata kunci: Bimbingan dan Konseling, Peserta didik SMA, Problematika Akademik

\section{PENDAhuluan}

Peserta didik SMA adalah individu yang memasuki masa remaja. Masa remaja merupakan suatu periode dimana manusia berada pada transisi dari masa kanak-kanak menjadi dewasa
(Santrock, 2012:402). Tugas perkembangan yang harus dicapai peserta didik SMA/remaja menurut Havighurst (Gunarsa \& Gunarsa, 2001) antara lain yaitu: 1) Tejadi penerimaan keyataan bahwa fisik akan mengalami perubahan dan mampu mengimplementasikan 
perannya secara efektif sesuai jenis, serta merasakan perasaan puas dengan keadaan tersebut; 2) Peserta didik mempelajari peran sosial yang ia miliki diantara teman sebaya perempuan maupun laki-laki; 3) Peserta didik mampu terlepas dari ketergantungan pada orang dewasa terutama orang tua; 4) Peserta didik mampu melakukan pengembangan kecakapan intelektual serta konsep lain berkaitan dengan kehidupan dalam masyarakat; 5) Peserta didik dapat melakukan pencarian jaminan terkait segala sesuatu dibidang ekonomi masa depan yang harus dilakukan secara mandiri; 6) Peserta didik mampu melakukan persiapan diri guna menentukan plihan pekerjaan yang sesuai dengan konsisi kesanggupan dan bakat pribadinya; 7) Peserta didik dapat mengerti dan mengimplementasikan bahwa perlakunya harus dapat dipertanggung jawabkan, dan sesuai dengan norma dan nilai yang berlaku dimasyarakat; 8) Peserta didik mendapatkan informasi mengenai pernikahan serta memiliki persiapan untuk berkeluarga; 9) Peserta didik memperoleh pemahaman bahwa caranya bersikap adalah tepat dan sesuai dengan pandangan ilmiah.

Peserta didik SMA jika dilihat dari segi emosional dapat digambarkan dengan keadaan yang tidak stabil dan seringkali meledakledak. Hal ini sesuai dengan pernyataan Hall (Sarwono, 2011) yaitu masa remaja adalah masa "sturm and drang" artinya masa yang penuh dengan emosi dan adakalanya emosi tersebut meledakledak dikarenakan terdapat pertentangan nilai-nilai. Tingginya emosional ini dapat dipengaruhi adanya tekanan dari tuntutan sosial terhadap penerimaan peran baru seperti layaknya orang dewasa. Keadaan seperti ini dapat memicu permasalahan pada diri peserta didik, misalnya mengalami kesulitan dalam belajar, penyalahgunaan obat terlarang (NAPZA), dan penyimpangan tingkah laku. Peserta didik yang tidak mampu mengontrol keadaan emosinya dapat mengarahkan ke hal-hal yang negatif dan dapat berpengaruh pada prestasi akademiknya.

Hasil proses belajar peserta didik dipengaruhi oleh faktor internal dan eksternal. Menurut Ahmadi (Elmirawati, Daharnis \& Syahniar, 2013: 107) faktor internal peserta didik meliputi minat bakat, kecerdasan, motivasi, dan kemampuan kognitif. Sedangkan faktor eksternal yang mempengaruhi yaitu lingkungan belajar, sarana dan fasilitas belajar, bahan belajar, kurikulum, dan guru pengajar.

Bidang akademik sampai saat ini masih menjadi salah satu problematika yang sering dialami peserta didik di SMA. Menurut Prayitno \& Amti (2009 : 279-280) terdapat 5 (lima) kategori masalah belajar, yaitu: 1) Keterlambatan akademik, yaitu kondisi peserta didik dengan inteligensi tinggi tetapi tidak dikembangkan secara optimal; 2) Ketercepatan dalam belajar, yaitu kondisi peserta didik dengan tingkat akademik yang tinggi memiliki IQ di atas 130 dan membutuhkan tugas tambahan/khusus untuk memenuhi kebutuhan belajar dengan kemampuan yang tinggi tersebut. ; 3) Sangat lambat dalam belajar, yaitu kondisi peserta didik dengan tingkat akademik yang rendah atau dapat 
dipertimbangkan untuk memperoleh pendidikan khusus; 4) Kurang motivasi belajar, yaitu kurangnya semangat dalam belajar yang dialami oleh peserta didik seperti malas untuk belajar; 5) Bersikap dan berkebiasaan buruk dalam belajar, yaitu kondisi peserta didik yang memiliki sikap serta kebiasaan yang kurang baik dalam belajar dan bertolak belakang dengan yang seharusnya, misalnya: sering menunda tugas, tidak suka atau membenci guru, tidak tepat waktu atau mengulur waktu, serta tidak bertanya mengenai hal-hal yang kurang dipahami.

Problematika yang dihadapi peserta didik SMA perlu diatasi oleh berbagai pihak, salah satunya adalah dari Konselor Sekolah/Guru BK. Dalam rangka penyelesaian problematika akademik, adanya intervensi melalui layanan Bimbingan dan Konseling sangat diperlukan. Menurut Prayitno \& Amti (2009) Bimbingan adalah suatu proses pemberian bantuan dari Konselor kepada Konseli melalui prosedur dan cara yang dapat memandirikan sehingga Konseli mampu memecahkan masalahmasalah yang dihadapinya. Sedangkan, konseling adalah suatu proses pemberian bantuan dari Konselor kepada Konseli berdasarakan wawancara konseling yang bertujuan menyelesaikan masalah yang dialami oleh Konseli. Jadi, Bimbingan dan Konseling adalah suatu proses pemberian bantuan melalui prosedur sistematis dengan cara memandirikan klien dalam upaya penyelesaian masalahmasalahnya agar mencapai perkembangan yang optimal.
Bimbingan dan Konseling komprehensif yaitu suatu program yang memiliki kerangka kerja organisasi yang spesifik dari kegiatan dan layanan bimbingan dan konseling yang direncanakan, diurutkan, dan terkoordinasi berdasarkan pada kebutuhan dan sumber daya siswa, sekolah, dan komunitas, yang dirancang dengan tujuan untuk melayani semua peserta didik dan wali/orang tua siswa di sekolah (Gysbers \& Henderson, 2012).

Lebih lanjut lagi Gysbers \& Henderson (2012 : 61) menyatakan program bimbingan dan konseling komprehensif memiliki standar yang mengidentifikasi pengetahuan dan keterampilan yang dipelajari siswa saat mereka terlibat dalam kegiatan dan layanan program komprehensif. Pengetahuan dan keterampilan (standar) ini dikelompokkan pengembangan akademik, karir, dan pribadi-sosial. Menurut ASCA (2004) Standar Akademik yang harus dicapai oleh peserta didik dalam Program Bimbingan dan Konseling Komprehensif yaitu: 1) Peserta didik akan memperoleh pengetahuan, sikap, dan keterampilan yang berkontribusi dalam pembelajaran efektif di sekolah dan selama rentang hidupnya; 2) Peserta didik dapat menyelesaikan sekolah melalui persiapan akademis yang matang dengan menetapkan pilihan dari berbagai pilihan besar pasca-sekolah menengah, termasuk jenjang perguruan tinggi; 3) Mahasiswa mampu memahami antara hubungan akademisi dengan dunia industri dan dengan kehidupan di keluarga serta di masyarakat. 
Sehingga, melalui layanan Bimbingan dan Konseling yang tepat diharapkan mampu untuk menyelesaikan berbagai problematika akademik yang dialami oleh peserta didik. Berdasarkan uraian teori diatas, penelitian ini bertujuan untuk mengetahui problematika apa saja yang dialami oleh peserta didik SMA beserta langkah-langkah tindakan yang dilakukan oleh peneliti sebelumnya. Melalui kajian literature diharapkan mampu menambah wawasan serta pemahaman mengenai alternatif solusi yang bisa dilakukan oleh calon guru BK (mahasiswa BK) maupun praktisi (guru BK) di sekolah dalam upaya membantu siswa mengatasi permasalahan akademiknya.

\section{METODE}

\section{a. Jenis Penelitian}

Jenis penelitian yang digunakan dalam penelitian Problematika Bimbingan dan Konseling Bidang Akademik Peserta Didik SMA ini adalah A Systematical Literature Review (SLR). Kitchenham (2004) mengemukakan bahwa systematical literature review merupakan suatu metode yang berupaya untuk mengidentifikasi, mengevaluasi, dan menginterpretasi keseluruhan hasil penelitian sesuai dengan pertanyaan penelitian, topik, ataupun fenomena yang menjadi kajian. Siswanto (2010) lebih lengkap menyebutkan bahwa proses sintesis terhadap berbagai hasil penelitian akan sangat terbantu dengan penggunaan metode penelitian systematical literature review, dimana fakta yang tersaji pada penentu kebijakan akan lebih komprehensif dan seimbang.

Penelitian dengan mereview literatur dilakukan untuk berbagai tujuan, diantaranya adalah untuk memberikan latar belakang teori untuk penelitian selanjutnya, mempelajari luasnya penelitian mengenai suatu topik yang menarik, atau menjawab pertanyaan praktis dengan memahami apa penelitian yang ada kaitannya tentang masalah tersebut (Ocoli \& Schabram, 2010).

Systematical literature review dalam penelitian ini dilakukan dengan melakukan penghimpunan artikel-artikel bimbingan dan konseling yang dipublikasikan mulai tahun 2010 hingga tahun 2020. Jumlah artikel awal yang diperoleh pada penghimpunan data mencapai 66 artikel yang kemudian direduksi berdasarkan kriteria (1) Fokus bidang akademik;

Kesesuaian dengan pertanyaan penelitian; (3) Kesesuaian dengan jenjang Pendidikan SMA, sehingga hanya dianalisis 21 artikel. Artikel diperoleh dari jurnal-jurnal bimbingan dan konseling serta jurnal pendidikan, baik berupa jurnal nasional maupun jurnal internasional. Artikel dikumpulkan dari jurnal: Jurnal Bimbingan dan Konseling Terapan, Insight: Jurnal Bimbingan dan Konseling, Jurnal Bimbingan Konseling, Jurnal Bimbingan Konseling Indonesia, Jurnal BK UNESA, Jurnal Kajian Bimbingan dan Konseling, Jurnal Riset Mahasiswa Bimbingan dan Konseling, Konseli: Jurnal Bimbingan dan Konseling, Teraputik Jurnal Bimbingan dan Konseling, Jurnal Psikologi Pendidikan \& Konseling: Jurnal 
Kajian Psikologi Pendidikan dan Bimbingan Konseling, Procedia Social and Behavioral Science, dan International Journal for CrossDeciplinary Subject in Education

\section{b. Prosedur Penelitian}

Prosedur penelitian systematic literature review dengan pendekatan kualitatif dilaksanakan dengan mengikuti langkah-langkah menurut Francis \& Baldesari (2006) yang terdeskripsikan dalam tabel dibawah ini.

Tabel 1. Langkah Prosedur Penelitian Systematical Literature Review Problematika Bimbingan dan Konseling Akademik pada Peserta Didik di SMA.

\section{Langkah penelitian Langkah yang menurut Francis \& dilakukan peneliti Baldesari (2006)}

\begin{tabular}{ll}
\hline 1) $\begin{array}{l}\text { Memformulasikan a) } \\
\text { pertanyaan }\end{array}$ & Merumuskan \\
penelitian & pertanyaan \\
(formulating the & penelitian yang \\
review question) & difokuskan \\
& pada \\
& problematika \\
& bidang \\
& akademik \\
& peserta didik di \\
& jenjang \\
& Pendidikan \\
& SMA. \\
& Membuat \\
& pertanyaan \\
& berikutnya \\
& yaitu upaya \\
& yang dilakukan \\
& oleh guru BK / \\
peneliti \\
sebelumnya \\
dalam \\
mengatasi \\
permasalahan \\
tersebut. \\
\end{tabular}

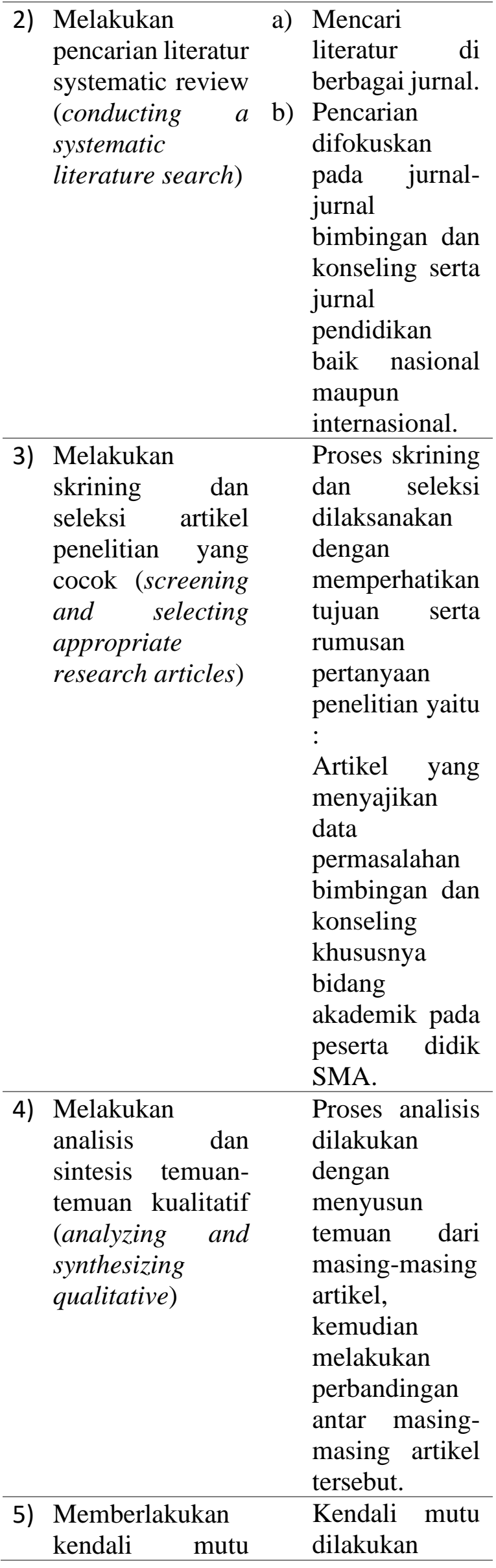




\begin{tabular}{ll}
\hline (maintaining & dengan \\
quality control) & melakukan \\
& konsultasi \\
& kepada dosen \\
& bimbingan dan \\
& konseling. \\
\hline 6) Menyusun & Laporan akhir \\
laporan akhir & dilaksanakan \\
(presenting & dengan cara \\
findings) & menulis artikel \\
& hasil penelitian \\
& yang kemudian \\
& dipublikasikan. \\
\hline
\end{tabular}

\section{c. Teknik Analisis Data}

Analisis data pada penelitian ini dilakukan dengan penggunaan metode meta-sintesis. Siswanto (2010) mengungkapkan bahwa dalam systematical literature review terdapat dua jenis metode yaitu metode meta-analisis dan metasintesis. Meta-sintesis adalah teknik pengintegrasian data guna memperoleh teori, konsep-konsep yang lebih baru, ataupun level pemahaman yang lebih dalam dan komprehensif (Perry \& Hammond, 2002).

Terdapat dua pendekatan yang dapat digunakan dalam melakukan meta-sintesis yaitu meta-agregasi dan meta-etnografi (Lewin, 2008). Pendekatan meta-sintesis yang digunakan pada penelitian ini adalah meta-agregasi, dimana tujuan utamanya adalah untuk menjawab pertanyaan-pertanyaan penelitian dengan melakukan perangkuman berbagai hasil penelitian khususnya yang terkait dengan problematika bidang akademik.

\section{Hasil dan Pembahasan}

Pada penelitian ini terdapat 21 artikel yang diterbitkan dalam kurun waktu sepuluh (10) tahun terakhir yakni pada tahun 2010-2020. Berdasarkan pengumpulan dan analisa dari berbagai artikel penelitian-penelitian terkait dengan Problematika Bimbingan dan Konseling Peseta Didik SMA pada bidang Akademik memunculkan beberapa data problematika dan upaya penanganannya sebagai berikut: 
Tabel 2. Problematika Peserta Didik SMA bidang Akademik.

\begin{tabular}{|c|c|c|c|c|c|c|c|c|c|c|c|c|c|}
\hline $\begin{array}{l}\text { Penulis. } \\
\text { Tahun }\end{array}$ & $\begin{array}{c}\text { Prokrastinasi } \\
\text { Akademik }\end{array}$ & $\begin{array}{l}\text { Hasil } \\
\text { Belajar } \\
\text { Rendah }\end{array}$ & $\begin{array}{c}\text { Keterampilan } \\
\text { Berbicara } \\
\text { Rendah }\end{array}$ & Cyberloafing & $\begin{array}{c}\text { Self- } \\
\text { afficacy }\end{array}$ & $\begin{array}{c}\text { Stress } \\
\text { Akademik }\end{array}$ & $\begin{array}{l}\text { Student } \\
\text { Truancy }\end{array}$ & $\begin{array}{c}\text { Meningkatkan } \\
\text { Student } \\
\text { Engagement }\end{array}$ & $\begin{array}{c}\text { Tanggung } \\
\text { Jawab } \\
\text { Belajar } \\
\text { Rendah }\end{array}$ & $\begin{array}{c}\text { Kemandirian } \\
\text { Belajar } \\
\text { Rendah }\end{array}$ & $\begin{array}{l}\text { Regulasi } \\
\text { Diri } \\
\text { Rendah }\end{array}$ & $\begin{array}{l}\text { Capaian } \\
\text { Akademik } \\
\text { Rendah }\end{array}$ & $\begin{array}{c}\text { Motivasi } \\
\text { Belajar } \\
\text { Rendah }\end{array}$ \\
\hline $\begin{array}{l}\text { Abnindanti, \& } \\
\text { Pratiwi. } \\
2020\end{array}$ & $\checkmark$ & & & & & & & & & & & & \\
\hline $\begin{array}{c}\text { Awanda, \& } \\
\text { Purwoko. } \\
2020\end{array}$ & $\checkmark$ & & & & & & & & & & & & \\
\hline $\begin{array}{c}\text { Ermanto. } \\
2020\end{array}$ & & $\checkmark$ & & & & & & & & & & & \\
\hline $\begin{array}{c}\text { Kurniawan, \& } \\
\text { Setiawati. } \\
2020\end{array}$ & & & $\checkmark$ & & & & & & & & & & \\
\hline $\begin{array}{c}\text { Manusakerti, \& } \\
\text { Purwoko. } \\
2020\end{array}$ & & & & $\checkmark$ & & & & & & & & & \\
\hline $\begin{array}{c}\text { Sari, \& Wiyono. } \\
2020\end{array}$ & & & & & $\checkmark$ & & & & & & & & \\
\hline $\begin{array}{c}\text { Anuar, Anas \& } \\
\text { Samad. } \\
2019\end{array}$ & & & & & & $\checkmark$ & & & & & & & \\
\hline $\begin{array}{c}\text { Hanim, \& Nisa. } \\
2019\end{array}$ & & & & & & $\checkmark$ & & & & & & & \\
\hline $\begin{array}{c}\text { Nisa, K., } \\
\text { Wibowo, M. E., } \\
\text { \& Awalya. }\end{array}$ & & & & & & & $\checkmark$ & & & & & & \\
\hline $\begin{array}{l}\text { Kurnaedi, } \\
\text { Sugiharto, \& } \\
\text { Sunawan. } \\
2019\end{array}$ & & & & & & & & $\checkmark$ & & & & & \\
\hline $\begin{array}{l}\text { Rohman, \& } \\
\text { Purwoko. } \\
2019\end{array}$ & $\checkmark$ & & & & & & & & & & & & \\
\hline $\begin{array}{l}\text { Andriati, \& } \\
\text { Rustam. } \\
2018\end{array}$ & & & & & & $\checkmark$ & & & & & & & \\
\hline $\begin{array}{l}\text { Mustamu. } \\
2018\end{array}$ & & $\checkmark$ & & & & & & & & & & & \\
\hline
\end{tabular}




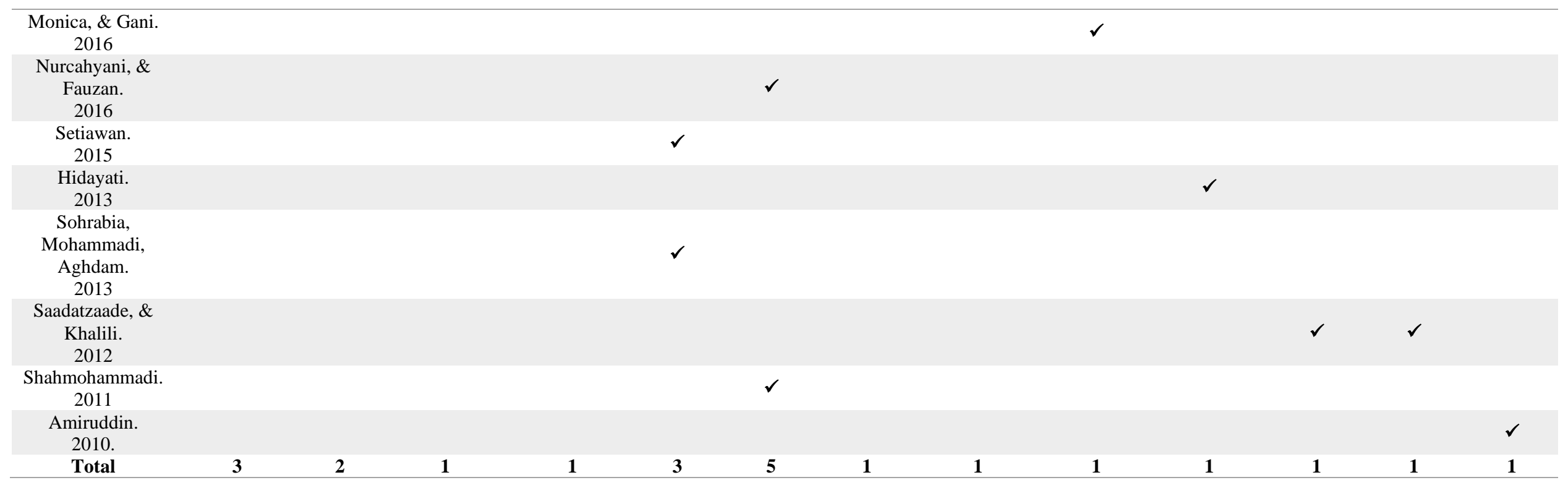

Tabel 3.1. Upaya Penanganan Problematika Peserta Didik SMA bidang Akademik

\begin{tabular}{|c|c|c|c|c|c|c|c|c|c|c|c|}
\hline $\begin{array}{l}\text { Penulis. } \\
\text { Tahun }\end{array}$ & $\begin{array}{c}\text { Cognitive } \\
\text { Behavior } \\
\text { Modification } \\
\text { Teknik Self- } \\
\text { Control }\end{array}$ & $\begin{array}{c}\text { Teknik Self } \\
\text { Managemen } \\
\text { dengan } \\
\text { Aplikasi } \\
\text { Any.do }\end{array}$ & $\begin{array}{l}\text { Cooperrative } \\
\text { Learning }\end{array}$ & $\begin{array}{l}\text { Modeling } \\
\text { Simbolik }\end{array}$ & $\begin{array}{c}\text { Konseling } \\
\text { Kelompok } \\
\text { Teknik self- } \\
\text { Control }\end{array}$ & $\begin{array}{l}\text { Cinema } \\
\text { Therapy }\end{array}$ & $\begin{array}{l}\text { Progressive } \\
\text { Muscle } \\
\text { Relaxation }\end{array}$ & $\begin{array}{l}\text { Video } \\
\text { Tutorial } \\
\text { Strategi } \\
\text { Problem } \\
\text { Focused } \\
\text { Coping }\end{array}$ & $\begin{array}{c}\text { Konseling } \\
\text { Kelompok } \\
\text { Behavioral } \\
\text { Teknik Self- } \\
\text { manajement dan } \\
\text { Reinforcement }\end{array}$ & $\begin{array}{c}\text { Clasical } \\
\text { Format } \\
\text { Mindfulness } \\
\text { Deep } \\
\text { Breathing }\end{array}$ & $\begin{array}{c}\text { Strategi } \\
\text { Self- } \\
\text { manajemen }\end{array}$ \\
\hline $\begin{array}{l}\text { Abnindanti, } \\
\text { \& Pratiwi. } \\
2020\end{array}$ & $\checkmark$ & & & & & & & & & & \\
\hline $\begin{array}{c}\text { Awanda, \& } \\
\text { Purwoko. } \\
2020\end{array}$ & & $\checkmark$ & & & & & & & & & \\
\hline $\begin{array}{c}\text { Ermanto. } \\
2020\end{array}$ & & & $\checkmark$ & & & & & & & & \\
\hline $\begin{array}{c}\text { Kurniawan, \& } \\
\text { Setiawati. } \\
2020\end{array}$ & & & & $\checkmark$ & & & & & & & \\
\hline
\end{tabular}




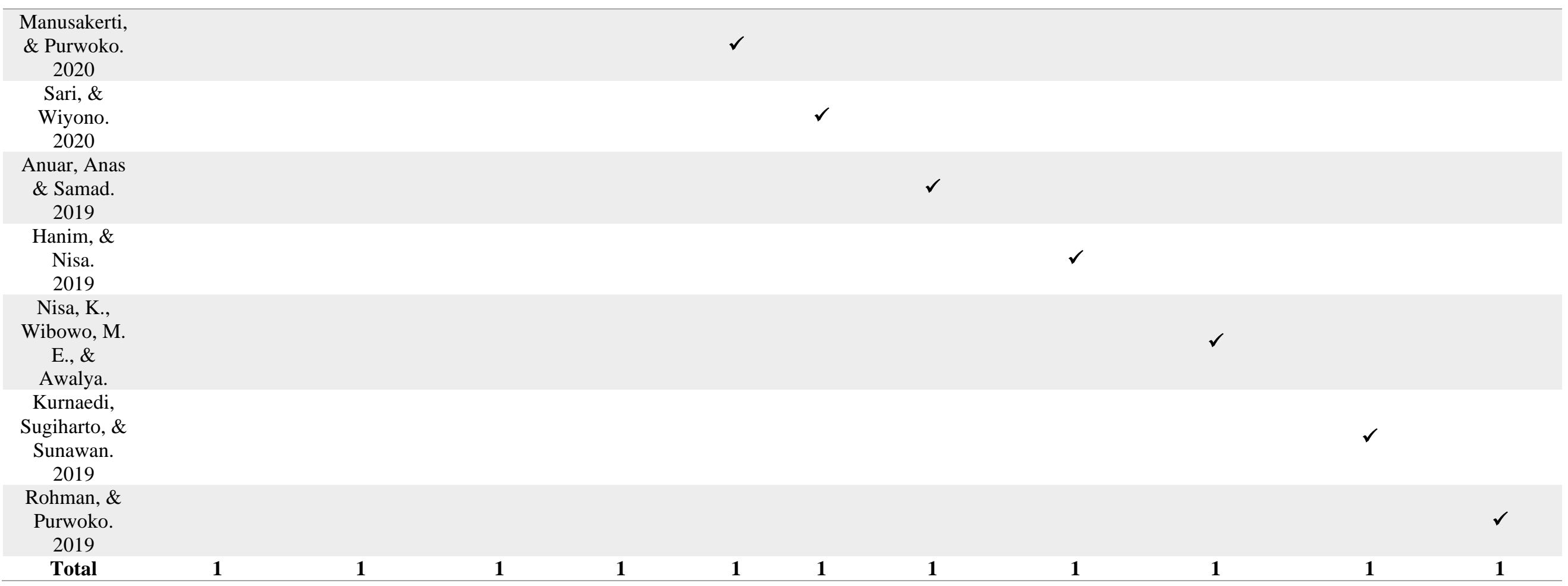

Tabel 3.2. (Lanjutan) Upaya Penanganan Problematika Peserta Didik SMA bidang Akademik

\begin{tabular}{|c|c|c|c|c|c|c|c|c|c|}
\hline $\begin{array}{c}\text { Penulis. } \\
\text { Tahun }\end{array}$ & $\begin{array}{c}\text { Bimbingan } \\
\text { Kelompok } \\
\text { Metode } \\
\text { Problem } \\
\text { Solving }\end{array}$ & $\begin{array}{c}\text { Contextual } \\
\text { Teaching and } \\
\text { Learning } \\
\text { dengan } \\
\text { Pendekatan } \\
\text { Ahli }\end{array}$ & $\begin{array}{l}\text { Konseling } \\
\text { Behavioral } \\
\text { Teknik Self- } \\
\text { Manajemen }\end{array}$ & $\begin{array}{c}\text { Teknik } \\
\text { Relaksasi }\end{array}$ & $\begin{array}{c}\text { Konseling } \\
\text { Kelompok } \\
\text { Teknik Problem } \\
\text { Solving }\end{array}$ & $\begin{array}{c}\text { Bimbingan } \\
\text { Kelompok } \\
\text { Teknik } \\
\text { Stimulus }\end{array}$ & $\begin{array}{c}\text { Konseling } \\
\text { Kelompok } \\
\text { Berbasis } \\
\text { Solusi }\end{array}$ & $\begin{array}{l}\text { Strategi } \\
\text { Coping }\end{array}$ & $\begin{array}{l}\text { Quantum } \\
\text { Learning }\end{array}$ \\
\hline $\begin{array}{c}\text { Andriati, \& } \\
\text { Rustam. } \\
2018\end{array}$ & $\checkmark$ & $\checkmark$ & & & & & & & \\
\hline $\begin{array}{c}\text { Mustamu. } \\
2018\end{array}$ & & & & & & & & & \\
\hline
\end{tabular}




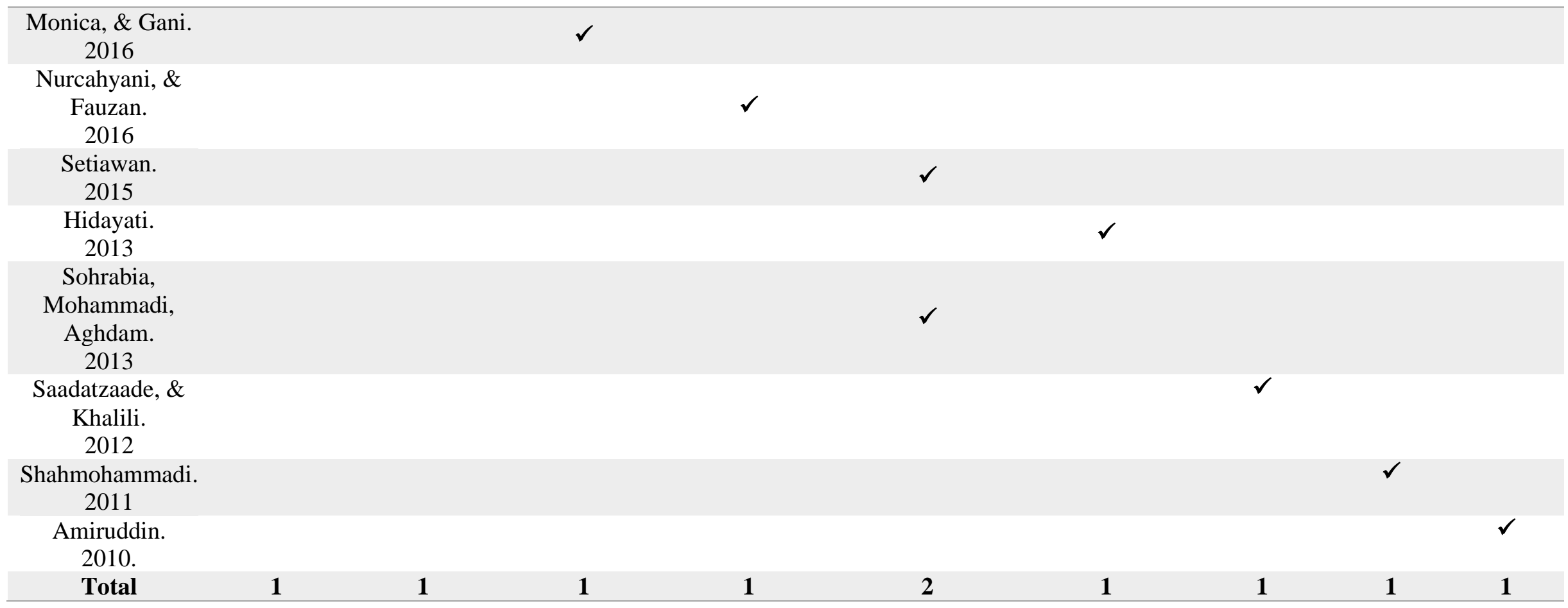


a) Problematika Bimbingan dan Konseling Akademik pada Peserta Didik SMA

Berdasarkan tabel 2 menunjukan beberapa problematika yang terjadi pada peserta didik SMA khususnya pada bidang akademik terdapat tiga belas (13) problematika yang terjadi pada peserta didik SMA diantaranya adalah, prokrastinasi akademik, hasil belajar rendah, keterampilan berbicara rendah, cyberloafing, selfefficacy, stres akademik, student truancy, meningkatkan student engagement, tanggung jawab belajar rendah, kemandirian belajar rendah, regulasi diri rendah, capaian akademik rendah, dan motivasi belajar rendah.

\section{b) Penaganganan Problematika Bimbingan dan Konseling Akademik pada Peserta Didik SMA}

Berdasarkan tabel 3 menunjukan hasil analisis terkait solusi dari problematika pada peserta didik SMA di bidang akademik. Terdapat dua puluh (20) upaya penanganan dari problematika pada peserta didik SMA pada bidang akademik, diantaranya adalah; cognitive behavior modification teknik selfcontrol, teknik self management dengan aplikasi any.do, cooperrative learning, modeling simbolik, konseling kelompok teknik self-control, cinema therapy, progressive muscle relaxation, video tutorial strategi problem focused coping, kelompok behavioral teknik self-manajement dan reinforcement, clasical format mindfulness deep breathing, strategi self-manajement, bimbingan kelompok metode problem solving, contextual teaching and learning dengan pendekatan ahli, konseling behavioral teknik self-manajemen, tekik relaksasi konseling kelompok teknik problem solving, bimbingan kelompok teknik stimulus, konseling kelompok berbasis solusi, strategi coping, dan quantum learning.

\section{c) Pembahasan}

Berdasarkan pengumpulan dan analisis beberapa artikel penelitian yang kami gunakan sebagai upaya mengindentifikasi problematika dan upaya penanganannya pada bidang akademik peserta didik SMA, tabel 2 menunjukan beberapa problematika bidang akademik pada peserta didik SMA yang beragam yang diantaranya prokrastinasi akademik, hasil belajar rendah, keterampilan berbicara rendah, cyberloafing, self-efficacy, stres akademik, student truancy, meningkatkan student engagement, tanggungjawab belajar rendah, kemandirian belajar rendah, regulasi diri rendah, capaian akademik rendah, dan motivasi belajar rendah. Pada tabel 2 menunjukan beberapa upaya penanganan yang dapat diterapkan dan dikembangkan dalam mengatasi problematika bidang akademik peserta didik SMA yang beragam diantaranya cognitive behavior modification teknik selfcontrol, teknik self management dengan aplikasi any.do, cooperrative learning, modeling simbolik, konseling kelompok teknik self-control, cinema therapy, progressive muscle relaxation, video tutorial strategi problem focused coping, kelompok 
behavioral teknik self-manajement dan reinforcement, clasical format mindfulness deep breathing, strategi self-manajement, bimbingan kelompok metode problem solving, contextual teaching and learning dengan pendekatan ahli, konseling behavioral teknik self-manajemen, teknik relaksasi, konseling kelompok teknik problem solving, bimbingan kelompok teknik stimulus, konseling kelompok berbasis solusi, strategi coping, dan quantum learning.

Menurut (Rohman \& Purwoko, 2019) Prokrastinasi dalam bidang pendidikan sering disebut dengan prokrastinasi akademik. Fauziah (Rohman, \& Purwoko.2019) Prokrastinasi merupakan gejalagejala yang diantaranya adalah menunda dalam mengerjakan tugas, sering datang terlambat, menunda belajar, dan belajar hanya pada saat ujian. Prokrastinasi akademik dapat diamati melalui ciri-ciri tertentu berupa: a) Penundaan untuk memulai menyelesaikan tugas yang dihadapi; b) Keterlambatan dalam menyelesaikan tugas, karena melakukan halhal lain yang tidak dibutuhkan; c) Kesenjangan waktu antara rencana yang ditetapkan dan kinerja aktual; d) Melakukan aktivitas lain yang lebih menyenangkan daripada tugas yang harus dikerjakan (refreshing).

Problematika yang terjadi pada peserta didik berikutnya adalah stress akademik. Stres akademik pada peserta didik muncul pada saat dalam meraih prestasi akademik meningkat, baik dari orang tua, guru ataupun teman sebaya, harapan tersebut sering kali kurang sesuai dengan potensi yang ada pada setiap individu (Shahmohamadi, 2011).

Penanganan dalam problematika di bidang akademik pada peserta didik SMA dapat diberikan upaya dalam menagatasi problematika yang terjadi dengan memberikan strategi layanan bimbingan dan konseling. Layanan bimbingan dan konseling merupakan suatu program pelayanan yang diperuntukan bagi siswa baik yang berupa layanan preventif atau kuratif bagi peserta didik atau konseli bermasalah maupun yang tidak bermasalah. Konselor yang profesional pada bidangnya dan program bimbingan dan konseling yang komprehensif (Fatchurahman, 2017). Strategi layanan yang cocok untuk diterapkan adalah salah satu layanan bimbingan dan konseling yakni layanan responsif, layanan responsif ini merupakan pemberian bantuan kepada peserta didik atau konseli yang mengalami kebutuhan dan masalah yang memerlukan penanganan segera (Fatchurahman, 2017).

Shertzer \& Stone

(Fatchurahman, 2017) mengemukakan konseling merupakan proses belajar dimana individu belajar tentang dirinya sendiri dan hubungan interpersonalnya dan adanya perubahan tingkah laku sebagai bentuk pengembangan dirinya. Penyelesaian masalah melalui layanan konseling dengan menggunakan teknik problem solving. Menurut Corey (Setiawan, 2015) problem soulving merupakan teknik dalam konseling kognitif behavior. Kognitif behavior adalah teknik yang dianggap paling efektif 
dengan menggunakan strategi perilkau kognitif yang memberikan bantuan kepada individu dapat megupayakan mengatasi masalah dalam kehdiupan sehari-hari mereka. Teknik problem solving ini dapat digunakan dalam strategi layanan dalam bimbingan dan konseling yakni konseling kelompok. Layanan konseling kelompok adalah bagian dari strategi layanan pada bimbingan dan konseling, yakni proses peyelesaian masalah yang upayakan penyelesaiannya secara berkelompok dan membentuk dinamika kelompok. Oleh sebab itu dalam situasi kelompok dinamika kelompok yang diwujudkan dalam konseling kelompok dapat saling memberikan saran dan masukan yang potensial, selain itu apabila terdapat anggota kelompok yang tidak berani mengungkapkan permasalahan, dengan konseling kelompok semua anggota kelompok berani dan mampu mengungkapkan permasalahannya sehingga memunculkan solusi dan potensi dalam upaya penyelesaian masalah.

Peran Guru BK dalam mengatasi problematika bimbingan dan konseling di bidang akademik ini sangat memiliki peran yang krusial dalam pengembangan potensi yang dimiliki oleh peserta didik. Guru BK juga berperan sebagai fasilitator untuk membantu peserta didik dalam pengembangan diri yang optimal seperti membantu dalam mencapai tugas perkembangan dan mengembangkan bakat minat peseta didik melalui pemberian layanan bimbingan dan konseling seperti layanan bimbingan klasikal, bimbingan kelompok, konseling individual maupun konseling kelompok.

\section{d) Simpulan}

Dari penelitian ini ditemukan korelasi yang efektif antara problematika akademik yang dialami oleh peserta didik SMA dengan solusi penanganan yg ditawarkan. Prokrastinasi akademik dan stres belajar dapat diupayakan penyelesaiannya dengan peran Guru BK dalam memberikan layanan bimbingan dan konseling. Layanan konseling kelompok melalui pendekatan kognitif behavior dan menggunakan teknik problem solving merupakan salah satu penanganan problematika akademik pada peserta didik SMA. Saran untuk peneliti selanjutnya adalah peneliti mampu mengkaji problematika bimbingan dan konseling di bidang akademik tidak hanya di tingkat Sekolah Menengah Atas (SMA), tetapi juga dapat mengkaji problematika bimbingan dan konseling bidang akademik pada jenjang pendidikan yang lain (SD, SMP, maupun SMK).

\section{REFERENSI}

Abnindanti, F. A., \& Pratiwi, T. I. (2020). Penerapan CognitiveBehavior Modification Teknik Self-Control Untuk Mengurangi Perilaku Prokrastinasi Akademik pada Peserta Didik di SMA Negeri 11 Surabaya. Jurnal BK UNESA. 11(3).

American School Counselor Association (ASCA). (2004). ASCA National Standards for Students. Alexandria, VA: Author. 
Amiruddin, I. (2010). Efektivitas Metode Pembelajaran Quantum Learning Terhadap Motivasi Belajar Siswa Kelas XI di SMA N 1 Pundong. Jurnal Riset Mahasiswa Bimbingan dan Konseling. 5(10).

Andriati, N., \& Rustam. (2018). Pengembangan Model Bimbingan Kelompok Melalui Metode Problem Solving untuk Meningkatkan Motivasi Belajar Siswa. Jurnal Bimbingan Konseling Indonesia. 3(1).

Anuar, A. B., Anas. M., \& Samad. S. (2019). Effects of Progressive Muscle Relaxation on Academic Stress in Students. Jurnal Psikologi Pendidikan \& Konseling: Jurnal Kajian Psikologi Pendidikan dan Bimbingan Konseling. 5(2).

Awanda, A. F., \& Purwoko, B. (2020). Pemanfaatan Aplikasi Any.do Dalam Teknik Self-Management Untuk Mengurangi Perilaku Prokrastinasi Akademik Siswa Kelas XI SMA YPM 2 Sukodono. Jurnal BK UNESA. 11(2)

Elmirawati, Daharnis, \& Syahniar. (2013). Hubungan antara Aspirasi Siswa dan Dukungan Orangtua dengan Motivasi Belajar serta Implikasinya terhadap Bimbingan dan Konseling. Jurnal Ilmiah Konseling. 2(1). Hal: 107-108.

Ermanto, P. (2020). Model Pembelajaran Kooperatif Sebagai Upaya Penerapan Layanan Bimbingan Konseling Belajar Siswa Kelas XI Sekolah Menengah Atas Negeri 1 Wongsorejo. TERAPUTIK Jurnal Bimbingan dan Konseling. 3(3).
Fatchurahman. (2017). Problematika Pelaksaan Konseling Individual. Jurnal Bimbingan dan Konseling Ar-Rahman. 3 (2). 25-30

Francis C. \& Baldesari (2006). Systematic Reviews of Qualitative Literature. Oxford: UK Cochrane Centre.

Gunarsa, S. D., dan Gunarsa, Y. S. (2001). Psikologi Praktis: Anak, Remaja dan Keluarga. Jakarta: BPK Gunung Mulia.

Gysbers, N. C., \& Henderson, P. (2012). Developing \& Managing Your School Guidance \& Counseling Program (5th ed). Alexandria, VA: American Counseling Association.

Hanim. W., \& Nisa, J. (2019). Pengembangan Video Tutorial Mengenai "Strategi Problem Focused Coping pada Stres Akademik dalam Menghadapi Ujian" untuk Peserta Didik Kelas X SMA Labschool Rawamangun Jakarta”. Insight: Jurnal Bimbingan dan Konseling. 8(1).

Hidayati, R. (2013). Model Bimbingan Kelompok Dengan Teknik Stimulus Control untuk Meningkatkan Kemandirian Belajar Siswa. Jurnal Bimbingan Konseling. 2(2)

Kitchenhamm, B. (2004). Procedures for Performing Systematic Reviews. Eversleigh: Keele University.

Kurnaedi, N., Sugiharto, D. Y. P., Sunawan. (2019). The Effectiveness of Mindfulness Deep Breathing in Classical Format to Increase Students' Academic 
Engagement. Jurnal Bimbingan Konseling. 10(1).

Kurniawan, A., \& Setiawati, D. (2020). Penerapan Strategi Modeling Simbolik untuk Meningkatkan Keterampilan Berbicara pada Siswa Kelas X IPS SMA Negeri 1 Menganti. Jurnal BK UNESA. 20(1).

Lewin, S. (2008). Methods to Synthesis Qualitative Evidence Alongside a Cochrane Intervention Review. London: London School of Hygiene and Tropical Medicine.

Manusakerti, G. A., \& Purwoko, B. (2020) .Teknik Self-Control Dalam Konseling Kelompok untuk Mengurangi Perilaku Cyberloafing pada Peserta Didik di SMA Negeri 5 Madiun. Jurnal BK UNESA. 11(4).

Monica, M. A., \& Gani, R. A. 2016. Efektivitas Layanan Konseling Behavioral dengan Teknik SelfManagement untuk Mengembangkan Tanggung Jawab Belajar pada Peserta Didik Kelas XI SMA Al-Azhar 3 Bandar Lampung Tahun Ajaran 2015/2016. KONSELI: Jurnal Bimbingan dan Konseling. 3(2).

Mustamu, B. (2018). Penerapan Model Pembelajaran Contextual Teaching And Learning dengan Pendekatan Tim Ahli Untuk Meningkatkan Hasil Belajar Siswa. Jurnal Bimbingan dan Konseling Terapan. 2(2).

Nisa, K., Wibowo, M. E., \& Awalya. (2019). The Effectiveness of Behavioral Group Counseling with Self-Management and Reinforcement Techniques to
Reduce Students' Truancy. Jurnal Bimbingan Konseling. 10(1).

Nurcahyani, I., \& Fauzan, L. 2016. Efektivitas Teknik Relaksasi dalam Konseling Kelompok Behavioral untuk Menurunkan Stres Belajar Siswa SMA. Jurnal Kajian Bimbingan dan Konseling. 1(1).

Ocoli, C., \& Schabram, K. (2010). A guide to conducting a systematic literature review of information system research. SSRN eLibrary. Retrivie from http://ddrn.com/abstract=1954824

Perry, A., \& Hammond, N. (2002). Systematical Review: The Experience of a PhD. Psychology Learning and Teaching. 2(1), 3235.

Prayitno \& Amti, E. (2009). DasarDasar Bimbingan dan Konseling. Jakarta: Rineka Cipta.

Rohman, A. A., \& Purwoko, B. (2019). Penerapan Strategi Self Management untuk Mengurangi Perilaku Prokrastinasi Akademik Siswa SMA Negeri 4 Sidoarjo. Jurnal BK UNESA. 10(3).

Santrock, J. W. (2012). Life Span Development Perkembangan Masa Hidup: Edisi ketiga Belas Jilid 1. Jakarta: Erlangga.

Sari, D. R., \& Wiyono, B. D. (2020). Cinema Therapy untuk Meningkatkan Academic SelfEfficacy Siswa Kelas XI-IPS SMA Negeri 4 Bojonegoro. Jurnal BK UNESA. 11(1).

Sarwono, S. (2011). Psikologi Remaja. Jakarta: PT. Rajagrafindo Persada. 
Setiawan, M. A., (2015). Model

Konseling Kelompok dengan

Teknik Problem Solving untuk Meningkatkan Self-Efficacy

Akademik Siswa. Jurnal

Bimbingan Konseling. 4(1).

Siswanto. (2010). Systemic Review sebagai Metode Penelitian untuk Mensintesis Hasil-Hasil Penelitian (Sebuah Pengantar). Surabaya: Pusat Penelitian dan Pengembangan Sistem dan Kebijakan Kesehatan.

Taufik, Ifdil \& Ardi. (2013). Kondisi Stres Akademik Siswa SMA Negeri Kota Padang. Jurnal Konseling dan Pendidikan. 1 (2). 143-150 